Tibor Rutar

\title{
The Rise of the Right in Times of Capitalist Crisis: A Materialist Explanation
}

Tibor Rutar is a PhD candidate at the Faculty of Arts in Ljubljana, Slovenia. He is a member of the Institute for Labour Studies and the editorial board of the Slovenian journal Borec. His PhD thesis is on the topic of Weberian and Post-Structuralist critiques of the core methodological and theoretical claims of historical materialism.

\section{Abstract}

In the article we aim to examine two pressing issues for any progressive, anti-capitalist movement or party today. The first concerns the (non-)success of classical Marxist attempts at providing a satisfactory account of workers' rising support for pro-capitalist ideology and political parties in times of economic crisis. The second relates to an updated attempt of a materialist explanation of this phenomenon.

\section{Introduction}

Pro-capitalist parties and movements of all political stripes - Right-Wing, Centrist and Center-Left - are booming even though, or perhaps precisely because, we're in the middle of a very deep capitalist crisis.
As the journalist Robert D. Kaplan puts it in his commentary on the 2014 European elections:

It is undeniable that the right wing is ascendant in Europe. While leftist parties did well here and there in recent elections to the European Parliament, the story over recent years has been mainly about the right, symbolized most dramatically by the soaring popularity of Marine Le Pen's National Front in France. But also in Denmark, Austria, Finland, the Netherlands, Switzerland and Serbia, the one commonality is the dynamism of nationalist-style political movements. Right-wing parties in France and Denmark got a quarter of the vote in late May's elections, while the right in Austria got a fifth. Meanwhile, the Jobbik party in Hungary and Golden Dawn in Greece have garnered headlines the world over for their flamboyant neo-fascist views and popularity among significant swathes of the voting public. ${ }^{1}$

1 Robert D. Kaplan, “Europe's Deep Right-Wing Logic,” Forbes, June 04, 2014, accessed October 29,2014, http://www.forbes. com/sites/stratfor/2014/o6/o4/europes-deep-right-winglogic/. 
These parties are not only booming but are even voted for by the working class itself. How can that be? Isn't it true, as Marxists have always contended, that the interests of workers are in direct opposition with the interests of capitalists and therefore in opposition with capitalism itself? Isn't it true that this is especially so in the middle of a serious capitalist crisis, when the exploitative, crisisprone nature of capitalism is revealed in full? It seems that it isn't true as it looks like workers don't recognize what their interests "truly are," and they decide not to support anti-capitalist, Socialist parties and movements, but instead support various pro-capitalist parties. How come there exists such an apparent contradiction? The classical answers to this puzzle typically refer to false consciousness, manipulation and workers' passivity, or they flat-out deny the puzzle itself and blame the so-called "aristocratic part" of the working-class for the parliamentary success of pro-capitalist politics in general and the Right-Wing in particular. In this article I will show that these classical answers are either too short or just plain wrong. I will also argue that underlying the success of pro-capitalist parties and politics are the actual material interests and life-experiences of voters (i.e. workers) and their rational behavior. ${ }^{2}$

2 Let us qualify this statement from the outset so as to avoid possible misunderstandings. Our claim is emphatically not that conservative ideology is to be explained wholly in terms of economic interests or, even more preposterously, that its genesis is reducible to "the economy" or "the capitalist mode of production." Our claim is only that a major part of the rise of pro-capitalist ideology (and, with it, conservatism) can be convincingly explained by reference to material interests and changing life-experiences of exploited agents in times of economic crisis.

\section{Two Classical Explanations of Workers' Support for Pro-Capitalist Ideology}

\section{(1) The "Labour Aristocracy Thesis"}

The fact that pro-capitalist ideas and parties are at least sometimes (or even usually) supported by workers has been explained by radical theorists oftentimes by referring to the so-called "Labour Aristocracy Thesis." This theory has many formulations, but in general there are three ${ }^{3}$ which have had a major impact: Marx's and Engels', Lenin's and Zinoviev's, and Elbaum's and Seltzer's. ${ }^{4}$ All three of them turn on two key points:

First, working-class conservatism is the result of material differences - relative privileges - enjoyed by some workers. Workers who embrace racism, nativism, sexism, homophobia and pro-imperialist patriotism tend to be those who earn higher wages, experience more secure employment, and have access to health-care, pensions and other forms of the social wage. Second, the source of this relative privilege ('the bribe') is a sharing of higher-than-average profits between capitalists and a privileged labouraristocracy. ${ }^{5}$

3 Charles Post, "Exploring Working-Class Consciousness: A Critique of the Theory of the 'Labour-Aristocracy," Historical Materialism 18 (2010): 3-38.

4 Post summarizes their interpretation thus: "Elbaum and Seltzer argue that the super-profits that account for the material privileges of the labour-aristocracy could not be 'reduced to excessive profit gains from "overseas investment."' Instead, super-profits resulting from monopoly - industrial concentration and the limitation of competition in key-sectors of the economy - produce higher-than-average wages and more-secure employment for a labour-aristocracy of unionised workers.” Post, "Exploring Working-Class Consciousness," 7.

5 Ibid., 6. 
The thesis is that pro-capitalist and conservative ideas in general, which make it harder for workers to unite and stand in solidarity with each other, are usually supported by the higher paid, better-off, privileged part of the working class; and that the sources of this privilege is the superprofit ${ }^{6}$ appropriated by capitalists in exchange and shared with some workers so as to pacify class struggle. In some versions of the thesis, the source of superprofit is imperialist intervention in less developed economies where labour costs are lower, in others the source is monopoly position of corporations in today's so-called

6 Superprofit (or, as originally termed by Marx, surplus profit) is an amount of surplus value that is appropriated by a technologically advanced capitalist or monopolist in exchange over and above the average amount of profit. As Marx briefly explains: "Just as a manufacturer who employs a new invention before it becomes generally used, undersells his competitors and yet sells his commodity above its individual value, that is, realises the specifically higher productiveness of the labour he employs as surplus labour. He thus secures a surplus profit [i.e. 'superprofit']." Karl Marx, Capital, 3 vols. (International Publishing, 1998), 3: 236. In other words, a company that is technologically more advanced than the average company can, in a competitive market, still sell its products at the price of the less advanced, average company (or only slightly under it so as to gain a larger market share). Even though the technologically advanced company's production costs are lower than average - because its technological superiority implies higher productivity - it can sell its products at the price which is set by average production costs of the majority of competing companies. This is so until all other companies in a sector themselves raise productivity through technological innovation. The extra profit enjoyed by the once technologically superior company is gone as all other (or at least the majority) companies also catch up to its level of productivity. To summarize, superprofit is enjoyed by those companies whose production costs are lower than the production costs of average (mean) companies, or by monopolist companies that can artificially boost the prices of their products. "monopoly capitalism." Now, why should higher-paid workers that are nonetheless subjected to exploitative practices in the workplace support pro-capitalist and conservative ideas instead of uniting with other workers and fighting against their common exploiters? According to the supporters of the "labour aristocracy thesis," it is so because by supporting pro-capitalist ideas and conservatism these higher-paid workers retain their relative privilege. By ideologically ${ }^{7}$ supporting capitalists they receive a bribe, a material reward, while at the same time they also help to maintain the stability of the source of their material reward by supporting imperialism, etc.

Charles Post has posed a major challenge to all types of this thesis both on theoretical as well as empirical grounds. Firstly, he claims that

[h]igher profits result in higher rates of investment across the economy in the industrialised countries. More investment eventually brings a growing demand for labour (within limits set by investment in newer, more capital-intensive technology), falling unemployment and rising wages for all workers in the industrialised capitalist countries. Put simply, imperialist investment in the global South benefits all workers in the global North - both 'aristocratic' steel, automobile, machine-making, trucking and construction-workers, and lowly-paid clerical, janitorial, garment- and food-processing workers as well. $^{8}$

7 In this article the term "ideology" will be used neutrally, simply as denoting any set of beliefs through which agents make sense of the world, no matter how false or true it is.

8 Post, "Exploring Working-Class Consciousness," 23. 
Secondly,

Howard Botwinick's study of wage- and profitdifferentials reviewed the literature published since Semmler's work was completed, and found similar patterns. Industrial concentration, again, could not explain profit- and wage-rate differentials. Not only were factors like labour-productivity and capitalintensity of production more important in accounting for profit- and wage-differentials, but many of the highly concentrated industries that had experienced higher-than-average profits prior to 1970 were experiencing lower-than-average profits in the $1970 \mathrm{~s}$ and 1980 s. More recent studies have confirmed the absence of a strong correlation between industrial concentration and higher-than-average profits and wages. Instead, profit and wage-differentials were rooted in the differentials in labour-productivity and capital-intensity of production. ${ }^{9}$

Thirdly and lastly,

[a] systematic review of the history of the workers' struggles in the global North in the past century does not bear out the claim that well-paid workers are generally conservative and poorly-paid workers are more radical. As John Kelly argued, '[h]istorically, the most class conscious and militant sections of the working class have often been those whose earnings, job security and status placed them in a position of relative privilege relative to many of their fellow workers. ${ }^{10}$

9 Post, "Exploring Working-Class Consciousness," 26.

10 Ibid., 28.
(2) The "False Consciousness Thesis"

or the "Dominant Ideology Thesis"

Sociological functionalism is a species of explanation that explains the existence of social phenomena by invoking their beneficial effects for, typically, the reproduction of the existing social order (or a certain social group). Functionalism is tightly, however not inextricably, linked to methodological holism, i.e. the notion that we can explain all social phenomena by referring only to social structures, "social facts" and "social laws," not individuals and their action. Holism relies on the explanatory power of social structures and "social facts" - instead of wants, beliefs, needs and interests of individual social agents - because it denies the existence of autonomous human agents or, what is the same, claims that agents are nothing else than the product of social structures, norms, rules and practices.

I have claimed that methodological holists are usually explanatory functionalists. This is so because in sociology there exist, in general, two species of explanations: intentional and functionalist explanations. Intentional explanations invoke agential wants, beliefs, interests and needs. Because holism denies the existence of autonomous agents and sees them wholly determined by "social facts", this type of explanation is ruled out $a$ priori. So holists are left with functionalism which, as we've already said, explains a phenomenon by invoking its beneficial effects for the reproduction of some other phenomenon. We can demonstrate how functionalism works by examining Louis Althusser's take on the capitalist state in his essay Ideology and Ideological State Apparatuses. For Althusser, the state in capitalist society is capitalist, i.e. it is tilted toward the interests of the ruling capitalist class, ${ }^{11}$ because it simply has

11 We've said that holists rarely invoke the needs or interests 
to reproduce capitalist conditions and relations of production. Althusser claims that a certain mode of production - say, capitalist mode of production - cannot exist, unless its conditions of existence are constantly being reproduced. ${ }^{12}$ This function of reproducing the conditions and relations of production in capitalist societies is done by the state.

[T]he Marxist-Leninist 'theory' of the State has its finger on the essential point, and not for one moment can there be any question of rejecting the fact that this really is the essential point. The State Apparatus, which defines the State as a force of repressive execution and intervention 'in the interests of the ruling classes' in the class struggle conducted by the bourgeoisie and its allies against the proletariat, is quite certainly the State, and quite certainly defines its basic 'function. ${ }^{, 13}$

The state succeeds in reproducing conditions and relations of production by two mechanisms: by the help of repressive and ideological state apparatuses. The

of individual agents because for them individual agents are irrelevant for explaining some social phenomena. Now, as we shall see in the case of Althusser, holists in their functionalist explanations can and do invoke the needs and interests of social groups or institutions, i.e. the needs and interests of ostensibly supra-individual, collective entities.

12 It is not at all controversial to say, as Althusser does, that something can exist only if its existence is being reproduced. In fact, it's a banal truism. The problem, however and as we shall see, is that it is not at all certain that the existing social order does in fact get reproduced. If there also exists constant class struggle, as Althusser himself affirms, merely claiming that the existing social order has to be reproduced begs the central question of how exactly this is possible.

13 Louis Althusser, Lenin and Philosophy and Other Essays (New York: Monthly Review Press, 1971), 137. latter are the more important for Althusser's case and will be of more interest to us as well.

[T] he Ideological State Apparatuses function massively and predominantly by ideology, but they also function secondarily by repression, even if ultimately, but only ultimately, this is very attenuated and concealed, even symbolic. (There is no such thing as a purely ideological apparatus.) Thus Schools and Churches use suitable methods of punishment, expulsion, selection, etc., to 'discipline' not only their shepherds, but also their flocks. ... [I]t is ultimately the ruling ideology which is realized in the Ideological State Apparatuses. ${ }^{14}$

According to Althusser - and consistent with his methodological holism - theideological state apparatuses via the power of discipline and indoctrination simply construct willing subjects, primed for the reproduction of capitalist conditions and relations of production. Agents are nothing else but the products of ideological interpellation, i.e. the prevailing social norms and rules; they are social constructs, top to bottom. From this we could arrive at a conclusion relevant for our general discussion. Namely, workers are supporting various procapitalist parties simply because they have succumbed to the ruling ideology which is being disseminated by the ideological state apparatuses. Because according to methodological holism agents are nothing but social products, this conclusion shouldn't come as a surprise. Relatedly, according to functionalism the fact that the existing social order is reproduced shouldn't come as a surprise either - it could never have been otherwise: the system is static.

14 Ibid., 145-146. 
This whole argument is summarized by three theorists who are otherwise sharp critics of the Dominant Ideology Thesis:

Through its control of ideological production, the dominant class is able to supervise the construction of a set of coherent beliefs. ... The dominant ideology penetrates and infects the consciousness of the working class, because the working class comes to see and to experience reality through the conceptual categories of the dominant class. The dominant ideology functions to incorporate the working class within a system which is, in fact, operating against the material interests of labour. The incorporation in turn explains the coherence and integration of capitalist society. ${ }^{15}$

One of the more influential proponents of this thesis and a follower of Althusser, Nicos Poulantzas, seems to accept such a characterization. This is what he says: "The dominant ideology, by assuring the practical insertion of agents in the social structure, aims at the maintenance (the cohesion) of the structure, and this means above all class domination and exploitation."16

This claim, I would argue, is profoundly mistaken. Firstly, methodological holism was shown to be unsatisfactory both on theoretical and empirical grounds a long time ago. Space limitations prevent us from presenting the main arguments against holism in any detail, but we can at least outline them. One problem with holism is that it cannot explain the transition from pre-social

15 Nicholas Abercrombie, Stephen Hill and Bryan S. Turner, The Dominant Ideology Thesis (London: George Allen and Unwin, 1980), 1-2.

16 Nicos Poulantzas, Political Power and Social Classes (London: Verso, 1974), 209. subject (or, in Althusserian terms, "individual") to fully socialized subject without presupposing what it set out to prove. This is especially acute in Althusser's theory of ideology which paradoxically presupposes the subject who is "always already" capable of recognizing herself in ideological interpellation, for the very purposes of explaining how such a subject is to arise. Another problem is that methodological holists cannot explain one of the most prominent socio-historical facts, which is that, throughout human history, agents of all cultures and societies have constantly struggled against prevailing social structures, norms, rules and practices or have even questioned all existing social ways and their continuation. Holists are also unable to explain how agents are able to construct for themselves entirely new ideologies and norms which have hitherto not existed.

Secondly, the applicability of functionalist explanations is much narrower than Althusser thinks. Simply claiming that phenomenon $\mathrm{X}$ exists because it has beneficial effects on the existence of phenomenon $\mathrm{Y}$ is a non sequitur, and such claims by themselves in any case never explain how and why phenomenon $\mathrm{X}$ emerged and is being reproduced. There are many social phenomena that have positive effects on the reproduction of social order, but which have emerged and exist independently of these positive effects. Gender inequality, for example, has positive effects on the reproduction of capitalist conditions and relations of production because it divides the working class and acts as a powerful barrier against class solidarity between male and female workers. However, it does not follow simply from this that gender inequality exists and is being reproduced for this reason. What is more, even if we accepted this "explanation" of gender inequality for the sake of argument, we haven't really explained much by it. We haven't explained neither how gender inequality came to exist nor which 
(individual or social) mechanisms are reproducing it, and how exactly this reproduction occurs.

To conclude, the influential ${ }^{17}$ Marxist (and, in a slightly different form, Parsoninan) "dominant ideology thesis," which claims that the ruling ideas in each epoch are the ideas of the ruling class or that the predominant ideology in each society and epoch is such that it successfully legitimizes the existing social order is false. From the mere fact that pro-capitalist ideas in general and RightWing ideas in particular have a positive influence on the reproduction of the existing social order, we cannot conclude that they came into existence for this reason, nor can we speculate about the reasons for their persistence and omnipresence.

\section{Materialist Explanations and Their Critics}

We have presented a few reasons for rejecting the classical explanations of working class support for procapitalist ideas and parties. I will now present a different, materialist ${ }^{18}$ explanation of this phenomenon that avoids

17 In The German Ideology Marx and Engels have, besides Althusser and Poulantzas, also mistakenly endorsed the Dominant Ideology Thesis. So has Terry Eagleton, in their name. See Terry Eagleton, Marxism and Literary Criticism (London: Routledge, 2002), 5 .

18 To avoid confusion it has to be said that the Labour Aristocracy Thesis is also a materialist explanation, but it is a materialist explanation that is, as we've seen, both empirically and theoretically flawed. The Dominant Ideology Thesis, however, is not a materialist explanation, but is rather a normative-functionalist one. The difference between materialist explanations and normative-functionalist explanations is most clearly and succinctly indicated by Parsons: "I am a cultural determinist. . . . I believe that ... the normative elements are more important for social change than ... material interests.” Talcott Parsons, Societies: Evolutionary the pitfalls of the classical explanations. In an article from the beginning of 1980 s Robert and Johanna Brenner have provided a succinct and convincing starting-point of exactly such analysis. They write:

Workers have moved right instead of left because of what they perceive to be - and what in a limited but important sense really are - their immediate, shortrun economic interests (however disastrous this may be in the long-run). It is this development which makes the politics and organization of the right a serious threat. ${ }^{19}$

Below we will try to expand on their essential point by defending the following three theses:

(a) There exist "good reasons" - i.e. their actual material interests - for workers to support procapitalist ideas in general and Right-Wing ideas in particular, especially in times of economic crisis.

(b) The Right-Wing addresses these true, actual needs and interests of workers, but it does so in a particular way that is, even though it is not simply false, one-sided.

(c) The Socialist Left should address the same interests and needs, but do so in a different, more forwardlooking way than the Right-Wing.

Many theorists - even Marxist theorists, especially the ones who were forged in the holist fire of Althusserianism - are usually skeptical of materialist explanations that

and Comparative Perspectives (New Jersey: Prentice-Hall, 1966), 113.

19 Robert Brenner and Johanna Brenner, "Reagan, the Right and the Working Class," Against the Current (Old Series) 1, no. 2 (1981), 29. 
refer to human needs and material interests. Therefore, let us examine the main arguments against materialist explanations before we continue with providing such an explanation. Post-Althusserian theorist Göran Therborn who sees himself working "on the basis of historical materialism" 20 presents his skepticism towards materialist explanations very clearly:

This notion of motivation by interest assumes that normative conceptions of what is good and bad and conceptions of what is possible and impossible are given in the reality of existence and are accessible only through true knowledge of the latter. In my opinion these are unwarranted and untenable assumptions. They represent a utilitarian residue in Marxism, which should be rejected, explicitly and decisively, once for all. ${ }^{21}$

This charge of "utilitarian residue in Marxism" is exactly what has been levelled against Vivek Chibber, the author of a recent tour de force Marxian work Postcolonial Theory and the Specter of Capital more recently. In this most recent work Chibber presented a materialist, interestbased Marxian analysis of Indian peasant and worker resistance. ${ }^{22}$ Critics (for example, Bruce Robbins ${ }^{23}$ ) are claiming - similarly to Therborn's concerns 35 years ago - that such an impoverished analysis makes out human agents to be pre-cultural rational automata who relentlessly calculate and maximize the personal utility of each and every social interaction and activity.

20 Göran Therborn, The Ideology of Power and the Power of Ideology (London: Verso, 1999), 5 .

21 Ibid.

22 Vivek Chibber, Postcolonial Theory and the Specter of Capital (London: Verso, 2013).

23 Bruce Robbins, "Subaltern-speak," $n+118$ (2013).
However, as Chibber notes in a response, ${ }^{24}$ these claims miss their target completely. It is, of course, true that conceptualizing agents in a Weberian way, i.e. as instrumentally rational, is unsatisfactory and mistaken, and it is even true that it was exactly this conception that was adopted by some of the most eminent selfproclaimed Marxists (Jon Elster, John Roemer and Adam Przeworski, to name just a few). But it does not follow from this bitter aftertaste that was left by Rational Choice Theory, Neo-Classical Economics and Analytical Marxism, that all references to material interests and their pursuit by "somewhat rational" agents have to be discarded.

To reiterate, agents are not - pace homo economicus instrumentally rational, that is, they are not necessarily self-interested, they do not relentlessly maximize their personal utility and they are not blind to the moral dimension of their ends. However, this doesn't mean that agents are not at least attitudinally and behaviourally rational. On the contrary, they usually act in a way at least consistent with (even if not optimal for) their interests and beliefs, and they also tend to eliminate beliefs that are mutually inconsistent. They are, furthermore, not only concerned with the means for achieving an end but also with the ends themselves. If we accept this non-utilitarian conception of agents we can have an interest-based analysis which is crucial for examining the connection between social structures and human agents, without succumbing to the siren song of orthodox rational choice theory that is rightly repudiated by most social scientists.

24 Vivek Chibber, "Subaltern Mythologies,” Jacobin (2014), accessed October 29, 2014, https://www.jacobinmag. com/2014/o1/subaltern-mythologies/. 
Now, there are some theorists that go even further than Robbins and Therborn. These theorists deny the very existence of material interests, even as conceptualized by non-utilitarian theories of agency. The Post-Althusserian historian Gareth Stedman Jones is a point in case:

The implicit assumption is of civil society as a field of conflicting social groups or classes whose opposing interests will find rational expression in the political arena. Such interests, it is assumed, pre-exist their expression.... We cannot ... decode political language to reach a primal and material expression of interest since it is the discursive structure of political language which conceives and defines interest in the first place. ${ }^{25}$

Something similar was claimed by a notorious pair of Post-Althusserian theorists, Barry Hindess and Paul Hirst: “Objects of discourse don't exist. Entities to which discourse refers are constituted in it and by it." And then we have yet another ex-Althusserian, Chantal Mouffe:

"How can it be maintained that economic agents can have interests defined at the economic level which would be represented a posteriori at the political and ideological levels? In fact, since it is in ideology and through politics that interests are defined, that amounts to stating that interests can exist prior to the discourse in which they are formulated and articulated. This is contradictory." ${ }^{27}$

25 Gareth Stedman Jones, Languages of Class: Studies in English Working Class History 1832-1982 (Cambridge: Cambridge University Press, 1983), 21-22.

26 Barry Hindess and Paul Hirst, Mode of Production and Social Formation (Basingstoke: Palgrave MacMillan, 1977), 20.

27 Chantal Mouffe, "Working Class Hegemony and the Struggle for Socialism," Studies in Political Economy 12 (1983), 9.
What all of these theorists claim, is that interests aren't given in advance of their politico-discursive expression. Interests can only be created, not given, and they are created only through political discourse and action. This means that interests cannot be objective and material, i.e. independent of the agent. They are arbitrary discursive constructs that, by definition, cannot be predicted in advance. Any Marxian insistence that all workers who are subjected to exploitation in the sphere of production have a material interest in the cessation or at least a toning down of exploitation is, according to aforementioned theorists, unwarranted. Until workers express their interest in explicit political language and through political action their interest simply doesn't exist, even though they might be subjected to constant exploitation and oppression.

These Post-Althusserians arrive at such an absurd, idealist conclusion by the help of some very fashionable, yet flawed sociological and philosophical arguments that aim to reject the existence of human nature and metaphysical realism. For the purposes of this article, let us merely "dogmatically" presuppose that there is a real world "out there," beyond our discourse, and that agents who are systematically exploited and oppressed have an objective interest (one among the many they have) for such an inhumane treatment of them to stop or to at least be diminished, even if they do not express this interest in explicit political discourse and action.

\section{The Paradox of Workers' Support for Pro-Capitalist Ideology}

We can now turn to our materialist thesis that is in contrast with all hitherto examined ones. I would argue that workers react positively to the promises of procapitalist parties because of real experiences and life- 
situations. These experiences that tilt workers further towards pro-capitalist ideology in times of economic crisis are, paradoxically and for the most part, created by the very insecurities of the labour market (i.e. rising rates of unemployment), stagnating or even regressing living standards, rising levels of exploitation in the workplace and the tendency for intensity of work to rise, that emerge from the capitalist mode of production and its law of competition. Said more briefly, one of the main reasons why workers support capitalist ideology is because of their real life experiences (not ruling class manipulation) that are themselves produced by the mechanisms of capitalist organization of social production. This seems utterly ironical, if not paradoxical. How is it possible that workers should support the very social order that is oppressive to them, and do so precisely because of experiencing how terrible it is, even though they are not the passive Althusserian "Träger" or Parsonian "cultural dopes"? In truth, it should not come as a surprise. Let's see why.

Pro-capitalist parties of all ideological stripes claim that in order for the unemployment rate to go down and for the new job offers to rise - or: for the crisis to subside the economy should be growing. But the economy can grow, they say, only if it is competitive enough, i.e. if it is conducive to profit-making. It is only in this case that foreign and domestic investors will be willing to invest in productive activities, and it is only when the rate of investment is rising that all economic actors (capitalists, workers, the state etc.) will see the rise of their revenue and personal income. Finally, it is only in such a booming economic situation that new jobs will be opening up, wages will be rising and the state will be able to sustain and expand its welfare projects and provisions (if this is prompted by struggles from below, of course). This, at least, is what the pro-capitalist parties, movements and ideologues claim. And we have to admit that they are correct - at least in the case of capitalist societies, i.e. in the case of currently existing arrangement of property relations.

It is true that in capitalism new job offers can be made, wages can be raised and the state can expand its welfare programs if and only if the economy is growing, and the economy can be growing only if it is competitive and profitable enough. This is so because the overwhelming majority of social production in capitalist societies is subordinated to the impersonal principle of market competition. This principle ensures that the companies which are not profitable or not profitable enough will, sooner or later, be bankrupt or taken over by other, more profitable companies: that is why no rational company which participates in the capitalist market would invest in non-profitable or not-profitable-enough economic activities. And, most importantly, in capitalism the source of all new revenue (that is profits, rents, wages, social benefits, taxes and so on; i.e. value and surplus value in Marxian terms) can only be the expanding economic activity of private companies - or, more precisely, the wage labour of workers employed by those private companies. So, to sum up the argument so far, even from a radical Marxian perspective it is safe to claim that if one wants to get the economy (and consequently the welfare-state) running in capitalism one has to get private business to invest in production.

The gradual decline of the general rate of profit, i.e. the ratio of newly generated profit to the value of invested capital, is, in fact, the underlying cause of capitalist crises. ${ }^{28}$ This claim is, of course, part of the infamous

28 See, for example, Andrew Kliman, The Failure of Capitalist Production: Underlying Causes of the Great Recession (London: PlutoPress, 2012); Guglielmo Carchedi, Behind the 
Marxian law of the tendency for the rate of profit to fall. It goes as follows: in times of economic boom (like the one that was experienced in the two decades after the Second World War) the rate of profit is at first high but then it gradually declines as capitalists introduce technological innovations in their production process so as to gain competitive advantage by raising the productivity of labour, i.e. the amount of produced goods in the same time period or with the same expenditure of labour. Higher productivity allows them to lower perunit production costs and gain market advantage over the technological laggards. The rate of profit gradually declines because rising productivity - even though it has beneficial short-term consequences for individual innovating capitalists - implies disinflation, i.e. falling rate of inflation. This usually means that sales revenue increases by less than production costs increase, which means that the nominal rate of profit falls. ${ }^{29}$

To put it in Marxian terms, by aiming to be more competitive and introducing technological innovations capitalists tend to displace labour-power from production. However, labour-power employed by private companies is the only source of profits (i.e. surplus value) which means that the general profit rate will tend to fall with the relentless introducing of new, labour-saving technology. Now, this displacement of labour-power is no issue for individual capitalists that are among the first to introduce new technology in their production

Crisis: Marx's Dialectics of Value and Knowledge (Leiden: Brill, 2011); Michael Roberts, The Great Recession. Profit Cycles, Economic Crisis. A Marxist View (LuLu Enterprises, 2009); Paul Mattick, Business as Usual. The Economic Crisis and the Failure of Capitalism (London: Reaktion Books, 2011).

29 Andrew Kliman, Reclaiming Marx's “Capital”: A Refutation of the Myth of Inconsistency (Lanham: Lexington Books, 2007), 129. process. This is so because they are able to appropriate the same or even more value in the sphere of exchange by producing more cheaply than their competitors, while at the same time selling the product at the same price as their less technologically advanced competitors. Displacement of labour-power becomes an issue only after it is generalized across a sector or industry. It is then that the per-unit sales value of product is lowered and the general nominal rate of profit tends to fall.

In other words and to summarize, because under the pressure of market competition - over time - profitability tends to drop (this happens when productivity of labour is rising) and because profitability is the main criterion of investment in capitalism, the rate of investment also gradually tends to drop. At that point all forms of revenue (most importantly, profit) start to decline and the road to economic stagnation is firmly secured. Competition, otherwise the main driver of capitalist productive dynamism, is at once its main retarding force. It is this conclusion that led Marx to claim, most famously in the Grundrisse, that capital is inherently contradictory.

It therefore shouldn't be surprising that a large part (especially the least paid part) of the working class is attracted to the rhetoric and ambitions of pro-capitalist parties, which strive to restore profitability and investment. It is not irrational to be attracted to such ideas in the short-run and in the absence of a convincing anti-capitalist alternative..$^{30}$

30 Social Democrats and Left-Keynesians (and also some selfproclaimed Socialists) argue that the solution for the crisis and stagnating economies is state-funded investment. Their suggestion is that the economy should be reignited by statefunded investment which is not vulnerable to the profit motive like private investment is. This argument overlooks the fact that state-funded investment is nothing else but investment 
Still, it has to be said that an important part of procapitalist rhetoric is misleading or at least one-sided. Firstly, even though it's true that new jobs can emerge only in conditions of economic growth and that the economy can grow only in conditions of a pleasant investment climate (i.e. conditions of high profitability),

which has taxes, i.e. the amount of surplus value produced by workers in private companies and then appropriated by the state, as its source. It should be obvious that state-funded investment can't be the motor of economic growth because such investment is not an independent source but is itself dependent upon the very economic growth that does not obtain in times of crisis. The real source of economic growth in capitalism is profit. State-funded investment that represents, directly or indirectly, a siphoning off of profit can be used, firstly, towards capitalist productive activity with the aim of generating as much new profit as possible. In this case the fact that the state (instead of a private company) expended money on production changes nothing, because the capitalist company would do the exact same thing, i.e. it would seek out the most profitable investment. State-funded investment can be used, secondly, towards non-capitalist productive activity which won't generate any new profit by definition as it was not mediated by market competition. In this case the fact that the state expended money on production changes matters for the worse because now money was expended and no new profit which could be reinvested was generated. The only remaining option is the intermediate one. That is, for the state to use money towards capitalist productive activity which is less than optimally profitable but which has explicitly beneficial effects on human lives and the environment. In this case the investment would generate, logically, less profit than it would if the state acted like a capitalist and searched for the most optimally profitable activity. The fact that it would have beneficial effects on human lives and environment changes nothing as far as ending the economic crisis goes. (Statefunded investment can be, alternatively, financed by the state going into debt. However, borrowing money can't be the means of ending a deep investment crisis, because all debts have to be repaid and the interest rates are usually extraordinarily high.) this growth is both limited ${ }^{31}$ and necessarily cyclical $^{32}$ which means that it goes against the interests of the working class at least in the mid- to long term. In other words and as argued above, every period of sustained economic growth in capitalism is necessarily followed by a period of stagnation and crisis: no amount of state regulation and public investment can prevent this. This is so because, as we've argued above, capitalist crises are fundamentally caused not by contingencies such as wrong political decisions, excessive financial speculation or economic fraud, but by rational and sensible actions of individual capitalist who, under the pressure of market competition, simply have to seek out more and more profitable investments if they are to remain capitalists. Capitalist crises cannot be done away with so long as economic activity is run along the axis of market competition. Those who claim so are not, contrary to what Milton Friedman and Richard Nixon famously claimed, all Keynesians - there are sound theoretical and empirical reasons not to be one.

Secondly, pro-capitalist rhetoric conveniently overlooks the very important fact that striving to raise the competitiveness of national economyin times of economic

31 The economy will grow only to the extent that capitalists are willing to invest, and they will invest only if this helps them survive market conditions. It would be irrational for them to increase investment when the prospects are gloomy.

32 As Marx put in Capital, Vol. 2: "one could only remark that crises are always prepared by precisely a period in which wages rise generally and the working class actually gets a larger share of that part of the annual product which is intended for consumption. . . . It appears, then, that capitalist production comprises conditions independent of good or bad will, conditions which permit the working class to enjoy that relative prosperity only momentarily, and at that always only as the harbinger of a coming crisis." Karl Marx, Capital, 3 vols. (International Publishing, 1996), 2: 409-410. 
crisis usually means a notable regression of workplace standards, downgrading of workers' rights and lowering of social transfers. It is only by doing this that labour costs can be lowered and, consequently, competitiveness increased. But the downgrading of workers' rights and lowering of social transfers is especially worrisome as it has disastrous mid- to long-term consequences: once rights are downgraded they have to be again seriously fought for in order to be restored at a later time.

These are two of the most important issues sidestepped by pro-capitalist rhetoric, and usually also overlooked by workers who support it. But to return to an earlier point, let's expand on the reasons that lead workers in times of crisis to increase their support for pro-capitalist ideas in general and Right-Wing ideas in particular.

In capitalism workers have a desperate need for employment. Because they have been stripped of virtually all means of making a living on their own, they usually have to seek out a job if they are to live. In times of crisis workers are more aware than ever of how important having a job really is. Pro-capitalists in general and the Right-Wing in particular seize on and address this desperate, real need of workers by emphasizing the importance of raising the competitiveness of the national economy. This "emphasis" usually takes the form of at least implicit if not explicit nationalism and patriotism. In other words, workers find these ideas at least somewhat appealing because they express - in however one-sided way - something that they really need and feel.

Relatedly, it is the real (not imputed!) experience of the worsening of conditions on the labour market, and the need for improving the position of domestic workers against the "cheaper foreign" labour-power that are at the heart of the sudden rise of workers' anti- immigrant leanings, xenophobia and discrimination in times of economic crisis. It is again the Right-Wing parties, movements and ideologues who seize on this real experience and need of workers, and propose discriminatory, anti-immigrant policies. It is thus that they strengthen xenophobia and anti-immigrant views among workers, not by outright manipulation and trickery.

Furthermore, it is again the real experience of witnessing many tycoon scandals, financial speculations and rising corruption some years before the crisis hit that procapitalist parties grab onto and use to substantiate their quasi-explanation of why the crisis happened. They say it was caused by the supposed disintegration of social (Christian?) values and an inefficient, corrupt juridical system, which prima facie seems wholly plausible because state and public-sector corruption, tax havens and greedy capitalist really do exist. In other words, by personalizing the crisis, by blaming it on personal defects of individual capitalist and state bureaucrats they inadvertently mystify the systemic causes behind the crisis, the rise of financial speculations and other bad investment decisions. They are at least partially successful in this because they appeal to real experiences of people. Lastly, the real fact that public debt has increased for most countries just before the crisis is again presented one-sidedly by the pro-capitalist parties. Rising public debt is presented as a consequence of a too large and expansive public sector, while the more systemic factors such as stagnating private investment are glossed over. ${ }^{33}$

33 Kliman presented strong empirical evidence for this last claim, at least for the American case: "[a]ll of the increase in the ratio of Treasury debt to GDP since 1970 is attributable to the falling profitability of U.S. corporations and reductions in corporate income tax rates. ... [State revenue from corporate income tax rates] fell partly because of a relative decline in 
In such circumstances - i.e., general economic crisis and increasing competition between workers on the one hand, and a failure of the Socialist Left to rigorously and convincingly address these issues on the other - it is not irrational for the majority of (worse-off) workers to rally behind the pro-capitalist Center-Left and Right-Wing. The needs, material interests and life experiences that motivate their support are not false and imputed. It is, however, true that the Center-Left and Right-Wing are addressing these needs and experiences one-sidedly. Pro-capitalist ideologies, parties and policies can be thriving only when the Socialist Left is down on its knees. Now, this last point is usually not overlooked by Socialists. But what is usually overlooked, is the fact that rising nationalism and xenophobia, to mention just the two most atrocious trends in the last few years, are two depressing phenomena that are, however, expressing actually existing social circumstances. They are neither the expression of workers' false consciousness nor capitalist conspiracy, as is so often claimed by Socialists, if only implicitly.

\section{Conclusion}

Putting this argument aside, it has to be admitted that the Socialist Left has traditionally called for internationalism and solidarity with migrant workers, even though it has often overlooked the real causes behind the rise of nationalism and xenophobia. This call is, of course, wholly commendable. Yet it is not nearly enough, in itself, if it is to be convincing and mobilizing. What

corporations' before-tax profits and partly because of reduced corporate tax rates. On average, before-tax profits equaled 11.6 percent of GDP between 1947 and 1969. Between 1970 and 2007, the average fell by almost one-fourth, to 8.8 percent." Kliman, Failure of Capitalist Production, 64; emphasis in the original.
Socialist organizations should do is to continually show (not merely declare) why exactly striving to increase competitiveness of the national economy and forcing immigrants out of the country will not in fact improve the economic ${ }^{34}$ position of the working class - at least not in the medium and long term.

Socialists should, firstly, convincingly show why supporting pro-capitalist parties and movements will worsen the economic position of the working class in the medium and long term. It has to be shown that market competition itself, not greedy bankers and rich capitalists, primarily causes serious economic instability and non-legitimate wealth inequality. This also means that Socialists who present socialism as a kind of "competitive advantage," something that will ostensibly solve the current crisis and pave the road to market success are missing the point completely (this is usually how socialism is presented by Social Democrats and Left-Keynesians).

To expand on this first point, let's briefly examine the case of workers' cooperatives under capitalism. Richard Wolff, a prominent Marxist economist, has been one of the more outspoken Socialist proponents of cooperatives in recent years. Like the majority of proponents of cooperatives, Wolff is also quick to defend them on the basis of their economic success and the resilience they shown in the face of current economic downturn. This, however, is very problematic. Even though no Socialist would doubt the importance of lower pay differentials that are characteristic of cooperative enterprises, there exist three major problems with regards to cooperatives.

34 Let alone the cultural and social devastation such conservative ideology leaves behind. 
Firstly, cooperatives are usually the exception, not the rule in capitalism. The defining characteristic of capitalism is private ownership of means of production. Capitalists own means of production and are willing to back their right to ownership at first by relying on the law and, if that doesn't do it, by relying on coercion. What is more, as Marx argued in Capital, vol. 1, market competition itself tends to, over time, concentrate means of production in fewer and fewer hands as inefficient companies get bankrupt and taken over by the more successful ones. His argument is supported by recent empirical evidence. ${ }^{35}$ It is, therefore, unlikely that workers would be able to peacefully convert the majority of traditional capitalist enterprises into cooperative ones.

Secondly, even in the unlikely case of this happening, the mere conversion of traditional enterprises into cooperative ones does not and cannot change the underlying distribution of property relations on which capitalism is based. This means that even the productive economic activity of cooperative enterprises is (or would be) regulated by laws of market competition. In other words, until capitalist property relations prevail between cooperatives, these will be subordinated to the profit motive, no matter how kind and nice their supposed non-capitalist owners are. This means that they'll still produce in order to stay afloat on the market even though by doing this they might be threatening the environment, increasing the rate of exploitation of workers, and paving the road to generalized economic collapse.

35 See, for example, the figures in William Marsden, "Obama's State of the Union Speech will be call to arms on wealth gap," Canada.com, accessible via: http://o.canada.com/news/ obamas-state-of-the-union-speech-will-be-call-to-arms-onwealth-gap.
Thirdly, Wolff himself admits that one of the most noted cooperatives, i.e. Mondragon, is "a stunningly successful alternative to the capitalist organization of production" precisely because it has as "a rule that all enterprises are to source their inputs from the best and least-costly producers - whether or not those are also MC enterprises." ${ }^{36}$ How exactly does sourcing inputs from "the least-costly producers" in order to remain as competitive on the market as possible make Mondragon Corporation an "alternative to the capitalist organization of production" is never explained by Wolff. This lack of explanation should not come as a surprise because Mondragon is not and has never been an alternative to capitalist organization of production.

The upshot of all this is most definitely not that workers' cooperatives have no place in the Socialist arsenal. Lower pay differentials are only one of the many progressive characteristics of cooperatives. The upshot, however, is that we should be honest. Cooperatives are not the alternative to capitalism, nor are they its end. They are not even an economic mechanism by means of which a serious investment crisis, like the present, can be remedied. But none of this means they are an unworthy short-term goal on the road to improve the living standard of workers.

Returning back to the beginning of this section, it is, secondly, on Socialist organizations to show, by theoretical and practical example, how mass strikes with the immigrants can improve even workers' short-term economic position. Strikes are one of the only effective

36 Richard Wolff, "Yes, there is an alternative to capitalism: Mondragon show the way," The Guardian, June 24, 2012 accessed October 29, 2014, http://www.theguardian. com/commentisfree/2012/jun/24/alternative-capitalismmondragon. 
tools in securing short-term economic improvements for workers, because it is only by hitting capitalists where they're most vulnerable - their profit-making ability - that some concessions can be granted even when times are tough. This is so because if it is more costly for capitalists to let the strike continue than to end it by conceding to workers' demands, they will go for the latter option. For strikes to be a real possibility workers have to, of course, be guaranteed at least the ability not to lose all their (meagre) personal savings amidst the strike when they're not getting paid by their employer. They also can't stand alone, if they are to avoid imminent defeat. This is where Socialist organizations can come in: by helping to provide a strike fund, and by helping with organizing and spreading solidarity.

In sum, if Socialist organizations are to gain in numbers, if they are to be again recognized by workers, rallied behind and mobilizing, they shouldn't primarily appeal to good faith and revolutionary spirit in times when a revolutionary event seems wholly implausible, if only because there are no revolutionary workers to begin with. They should first and foremost address the actually existing immediate needs and interests of workers (in a way radically opposed to Liberal-Left and Right-Wing proposals), not condemn the so-called "reformist" struggles for higher wages and more jobs as unworthy. Relatedly, they should be honest in their explanation of the crisis, the rise of the Right and in their calls for socialism. The crisis really is a crisis of investment and competitiveness, as some of the ideologues claim; the Liberal Left and Right-Wing haven't achieved such quite large working-class support by outright trickery or magic; for socialism to be back on the agenda, workers will have to rally behind the socialist project, but this can only happen if workers themselves start developing such socialist consciousness through mass strikes, various "reformist" struggles where solidarity is on display etc. Socialist organizations can't (and mustn't) impute socialist consciousness to workers from above, without it having any anchorage in their real experiences and material interests. 